\section{Effect of Silver Nanoparticles on Physicochemical and Antibacterial Properties of Calcium Silicate Cements}

Fernando Vazquez-Garcia1, Mário Tanomaru-Filho1, Gisselle Moraima Chávez-Andrade ${ }^{1}$, Roberta Bosso-Martelo², Maria Inês Basso-Bernardi', Juliane Maria Guerreiro-Tanomaru ${ }^{1}$
'Department of Restorative Dentistry, Araraquara Dental School, UNESP - Universidade Estadual Paulista, Araraquara, SP, Brazil

${ }^{2}$ Department of Dental Clinic, Dental School, UFBA - Universidade Federal da Bahia, Salvador, BA, Brazil ${ }^{3}$ Physics Institute, USP - Universidade de São Paulo, São Carlos, SP, Brazil

Correspondence: Mário TanomaruFilho, Rua Humaitá, 1680, Centro, 14.801-903Araraquara, SP, Brasil. Tel: +55-16-3301-6391. e-mail: tanomaru@uol.com.br

\author{
Key Words: Enterococcus \\ faecalis, silver nanoparticles, \\ physicochemical, antibacterial, \\ calcium silicate cement.
}

\begin{abstract}
Mineral trioxide aggregate (MTA) and Portland cement (PC) are calcium silicate cements. They have similar physicochemical, mechanical and biological properties. The addition of zirconium oxide $\left(\mathrm{ZrO}_{2}\right)$ to PC provides radiopacity. Silver nanoparticles (AgNPs) may improve some properties of cements. The aim of this study was to evaluate the effect of AgNPs on physicochemical/mechanical properties and antibacterial activity of white MTA (WMTA) and PC associated with $\mathrm{ZrO}_{2}$. The following materials were evaluated: WMTA; PC 70\% + $\mathrm{ZrO}_{2}$ 30\%; WMTA + AgNPs; and PC 70\% + $\mathrm{ZrO}_{2} 30 \%+$ AgNPs. The study evaluated radiopacity, setting time, $\mathrm{pH}$, compressive strength and solubility. For radiopacity analysis, radiographs were made alongside an aluminum (Al) step wedge. To evaluate the antibacterial activity, direct contact test was performed on planktonic cells and Enterococcus faecalis biofilm induced on bovine root dentin for 14 days. The experimental periods were 5 and $15 \mathrm{~h}$. Data were obtained as CFU $\mathrm{mL}^{-1}$. The obtained data were submitted to ANOVA and Tukey tests $(p<0.05)$. The addition of AgNPs to WMTA increased the $\mathrm{pH}$, lowered the solubility and the initial and final setting times. The addition of $\mathrm{AgNPs}$ to $\mathrm{PC} / \mathrm{ZrO}_{2}$ maintained the $\mathrm{pH}$, lowered the solubility, and increased the setting time and compressive strength. The radiopacity of all materials was higher than $4 \mathrm{mmAl}$. The addition of AgNPs promoted an increase in antibacterial activity for calcium silicate cements and favored the physicochemical and mechanical properties of the materials.
\end{abstract}

\section{Introduction}

The physicochemical, mechanical and biological properties of Mineral Trioxide Aggregate (MTA) and Portland cement (PC) are similar (1). The MTA consists of tricalcium silicate, dicalcium silicate, bismuth oxide (B0) and calcium sulfate traces (2). The tricalcium and dicalcium silicates are the main components of PC. BO may affect the physicochemical and biological properties of MTA (3). Addition of zirconium oxide $\left(\mathrm{ZrO}_{2}\right)$ to MTA and $P C$ can improve the physicochemical and antimicrobial properties of materials (4). Addition of $30 \% \mathrm{ZrO}_{2}$ does not affect the hydration of $\mathrm{PC}$ and originates bioactive cement with properties similar to MTA (5). $\mathrm{ZrO}_{2}$ may be a proper alternative as radiopacifier agent in substitution to BO providing physicochemical, mechanical and biological properties to calcium silicate cements. The association of $\mathrm{PC}$ with $30 \% \mathrm{ZrO}_{2}$ shows radiopacity, compressive strength, setting time, water absorption and solubility similar to MTA. Furthermore, the association promoted proper $\mathrm{pH}$ and calcium ions release $(3,4,6)$.

MTA presents some disadvantages like long setting time, difficulty for manipulation, and limited antimicrobial effect (7). Metallic nanoparticles may improve the physicochemical, mechanical and antibacterial properties of dental materials. Silver particles are used as alternative radiopacifier agents in calcium silicate cements (8). Silver $\left(\mathrm{Ag}^{+}\right)$added to calcium phosphate bone cements improved physicochemical properties, such as setting time, presented anti-adhesion and antibiofilm activity and showed noncytotoxic effect with human bone cells (9).

Silver nanoparticles (AgNPs) have been evaluated for several applications in Dentistry, such as root-end filling materials and dental implants (10), due to its effect as an antimicrobial agent $(11,12)$. AgNPs have been incorporated to composite resin $(12)$ and MTA $(7,13)$ in order to improve physical and antibacterial properties of the materials.

Samie et al. (13) evaluated the antimicrobial effectiveness of MTA mixed with AgNPs against various microbial species, observing that the addition of AgNPs to MTA enhanced the antimicrobial effect. Bahador et al. (11) also showed that AgNPs can effectively enhance the antibacterial activity of MTA against important anaerobic periodontal-endodontic pathogens with clinical applications for infection control in endodontics.

The aim of this study was to evaluate the effect of AgNPs on physicochemical and mechanical properties, and antibacterial activity of MTA and $\mathrm{PC} / \mathrm{ZrO}_{2}$. The null 
hypothesis was that the AgNPs do not interfere in the properties of calcium silicate cements.

\section{Material and Methods}

Polyvinyl alcohol (PVA)-coated AgNPs solution was synthesized by the Physics Institute - USP (São Carlos, $\mathrm{SP}, \mathrm{Brazil}) . \mathrm{AgNO}_{3}\left(1 \mathrm{mmol} \mathrm{L}^{-1}\right)$ was dissolved in $30 \mathrm{~mL}$ of ultrapure water (MilliQ-Plus ${ }^{\circledR}$ ) to which $30 \mathrm{~mL}$ of PVA was added. AgNPs capped with PVA were synthesized by reduction of $\mathrm{AgNO}_{3}$ solution in $\mathrm{NaBH}_{4}$ under constant stirring for $2 \mathrm{~h}$. The NPs solution was washed by centrifugation at 15,000 rpm for $1 \mathrm{~h}$ to remove the excess of reducing agent. Silver nanoparticles were obtained with a size range of 4-11 nm. The solution concentration was $53 \mathrm{ppm}$.

For the preparation of mixture nanoparticles/cements, AgNPs solution was added to the preestablished volume of PC 70\%/ZrO2 30\% or to WMTA powder. The experimental materials and their powder-liquid ratios are in Table 1.

\section{Radiopacity}

The radiopacity was assessed according to International Standard ISO 6876:2012 (14).

Specimens measuring $10 \mathrm{~mm}$ diameter by $1 \mathrm{~mm}$ high were made from each material $(n=6)$. The specimens were maintained at $37{ }^{\circ} \mathrm{C}$ and $100 \%$ humidity for $48 \mathrm{~h}$. After that, they were radiographed alongside an aluminum stepwedge graduated from 2-16 mm, using an occlusal film (Insight - Kodak Corp., Rochester, NY, USA). A GE 1000 $\mathrm{X}$-ray equipment (General Electric, Milwaukee, WI, USA) set at $60 \mathrm{kV}, 7 \mathrm{~mA}$, and 18 pulses per second was used with a focus-film distance of $30 \mathrm{~cm}$. The obtained images were digitized and evaluated by the Image J software $(\mathrm{NIH}$, Bethesda, MD, USA). Each step of the aluminum step-wedge was compared to the specimens, in order to determine the radiopacity of the cements (expressed in millimeters of aluminum - mmAl).

\section{Setting Time}

In order to determine the setting time $(n=10)$, specimens of $10 \mathrm{~mm}$ diameter by $1 \mathrm{~mm}$ high were made from each material $(n=6)$. To determine the initial setting, a Gilmore needle with a $100 \pm 0.5 \mathrm{~g}$ mass and $2 \pm 0.1 \mathrm{~mm}$ diameter was carefully placed vertically on the surface of each specimen, according to the International Standard ISO 6876:2012 (14).

After the initial setting was established, the measurements continued until the final set. The specimens were maintained at $37{ }^{\circ} \mathrm{C}$ throughout the analysis. For determination of the final set, the same procedure was performed by a Gilmore needle with a $456 \pm 0.5 \mathrm{~g}$ mass and a $1 \pm 0.1 \mathrm{~mm}$ tip diameter, as established by ASTM standard C-266-03 (15).

\section{Compressive Strength}

For assessment of the compressive strength, specimens ( $n=6$ ) were made according to BSI 6039:1981 (16). Samples were placed in cylindrical molds measuring $12 \mathrm{~mm}$ high and $6 \mathrm{~mm}$ diameter. The specimens were maintained at 37 ${ }^{\circ} \mathrm{C}$ and $95 \%$ humidity for $3 \mathrm{~h}$. The compressive strength of the materials was evaluated after $24 \mathrm{~h}$ and 21 days using a Universal testing machine (Emic DL 2000, Curitiba, PR, Brazil) with a $5 \mathrm{kN}$ load cell at $0.5 \mathrm{~mm} / \mathrm{min}$ crosshead speed.

The maximum tension the material was able to withstand was calculated and expressed in $\mathrm{MPa}$, taking into account the diameter of the specimens $\left(1 \mathrm{~Pa}=1 \mathrm{~N} / \mathrm{m}^{2}\right)$.

pH

Assessment of the $\mathrm{pH}(\mathrm{n}=10)$ was performed as described by Faria-Junior et al. (17), using $7 \mathrm{~mm}$ diameter by $1 \mathrm{~mm}$ high cement specimens. The $\mathrm{pH}$ was evaluated at 2 and 7 days after mixing. The samples were placed in plastic flasks containing $10 \mathrm{~mL}$ of deionized water with previously measured $\mathrm{pH}$. Flasks were closed and maintained at $37^{\circ} \mathrm{C}$. The water $\mathrm{pH}$ was assessed at $5 \mathrm{~h}$ and $15 \mathrm{~h}$ after immersion of the specimens by means of a previously calibrated $\mathrm{pH}$ meter. After each measurement, the mean $\mathrm{pH}$ of each experimental group was calculated. All measurements were performed in triplicate.

Table 1. Materials assigned to the four experimental groups

\begin{tabular}{|c|c|c|c|}
\hline Group & Material & Manufacture & $\begin{array}{l}\text { Powder/liquid } \\
\text { ratio }(\mathrm{g} / \mu \mathrm{L})\end{array}$ \\
\hline WMTA & WMTA + distilled water & Angelus Soluções Odontologicas, Londrina, PR, Brazil & $1 / 330$ \\
\hline $\mathrm{PC} / \mathrm{ZrO}_{2}$ & $\begin{array}{l}\mathrm{PC} 70 \%+\mathrm{ZrO}_{2} 30 \% \\
\pm \text { distilled water. }\end{array}$ & $\begin{array}{l}\text { PC: CPB-40 estrutural Votoran, Votorantin, Pedro Leopoldo, } \\
\text { MG, Brazil. } \mathrm{ZrO}_{2} \text { : Sigma Aldrich Corp. St. Louis, MO, USA }\end{array}$ & $1 / 330$ \\
\hline WMTA/AgNPs & $\begin{array}{l}\text { WMTA + AgNPs } \\
\text { solution (53 ppm) }\end{array}$ & AgNPs: Physics Institute - USP, São Carlos, SP, Brazil & $1 / 440$ \\
\hline $\mathrm{CP} / \mathrm{ZrO}_{2} / \mathrm{AgNPs}$ & $\begin{array}{l}\mathrm{PC} 70 \%+\mathrm{ZrO}_{2} 30 \% \\
+ \text { AgNPs solution. }\end{array}$ & PC: CPB-40 estrutural Votoran Votorantin, Pedro Leopoldo, MG, Brazil & $1 / 330$ \\
\hline
\end{tabular}

WMTA: white mineral trioxide aggregate; $\mathrm{ZrO}_{2}$ : zirconium oxide; PC: Portland cement; AgNPs: silver nanoparticles. 


\section{Solubility}

According to Faria-Junior et al. (17), specimens similar to those used in the $\mathrm{pH}$ tests were made $(\mathrm{n}=10)$. After filling the molds with the prepared cements, a $5 \mathrm{~cm}$ piece of dental floss was attached to one side of the specimen. After 2 and 7 days setting, the specimens were removed from the molds, and after removal of residues or loose particles, they were placed in a silica desiccator. After $1 \mathrm{~h}$, the specimens fixed with a piece of floss, were weighed in a BL 210S (HM-200; A \& D Engineering, Inc., Bradford, $M A, U S A)$ precision scale to obtain the initial mass. Each specimen was suspended by the floss in a plastic container with $10 \mathrm{~mL}$ deionized water, avoiding contact between the specimen and the container inner walls. Specimens were placed at $37^{\circ} \mathrm{C}$ for $15 \mathrm{~h}$.

After that, the samples were removed from the containers and rinsed with distilled and deionized water. The materials were kept in oven at $37^{\circ} \mathrm{C}$ for $15 \mathrm{~h}$. After that, the samples were removed from the containers, rinsed with distilled and deionized water, dried using filter paper, and placed in the silica desiccator for $24 \mathrm{~h}$ prior to a new weighing, in order to determine the final mass.

The results obtained in all tests were subjected to normality testing, and subsequently to ANOVA parametric test and Tukey multiple comparisons test $(p<0.05)$

\section{Antibacterial Activity}

Direct contact test against planktonic cells and biofilm formed in vitro was used. The strain selected for this study was Enterococcus faecalis (ATCC 29212). The direct contact test against planktonic cells was performed according to previous studies $(18,19)$. This test is based on the turbidimetric measurement of bacterial growth using 96-well microliter plates. Each material was mixed and placed in the wells. Six wells were used for each material. Then, $10 \mu \mathrm{L}$ of E. faecalis suspension was placed directly onto the samples for $30 \mathrm{~min}$. The positive control group received inoculum and no material. Two negative controls used were used with material and sterile culture medium, and with sterile culture medium and no material. The plates were kept in a laminar flow chamber for 30 min to assure direct contact between bacterial inoculum and the tested material surface (19). After this, $250 \mu \mathrm{L}$ of sterile BHI broth was added into each well, and into the positive and negative controls. The plates were incubated at $37^{\circ} \mathrm{C}$ in a microaerophilic environment for 5 and $15 \mathrm{~h}$ contact periods.

After the contact time, an aliquot of $10 \mu \mathrm{L}$ was removed from each well and placed in a new plate with $250 \mu \mathrm{L}$ of $\mathrm{BHI}$ broth. This new plate was incubated at $37{ }^{\circ} \mathrm{C}$ in a microaerophilic environment for $5 \mathrm{~h}$. This period is based on the previously studied $E$. faecalis growth curve. After this period, a spectrophotometer (UVM 340 ASYS; Nova
Analitica Ltda., São Paulo, SP, Brazil) was used to evaluate the turbidity of the medium. The absorbance $(\mathrm{Ab})$ reading was at $600 \mathrm{~nm}$ wavelength. The following formula was applied to the data: $A b_{\text {final }}=A b$ (material with inoculum) - Mean Ab (material without inoculum). The $A b_{\text {final }}$ values were analyzed using ANOVA test and comparison among the groups was performed using the Tukey test $(p<0.05)$.

The direct contact test against $E$. faecalis biofilm was performed according to Faria-Junior et al. (17) and Guerreiro-Tanomaru et al. (4). Bovine central incisors were used to induce biofilm formation. Dentine blocks measuring $5 \times 50.7 \mathrm{~mm}$ (width $\mathrm{x}$ length $\mathrm{x}$ thickness) were prepared using a diamond disc (Isomet; Buehler) at low speed, under irrigation. The blocks were placed in a test tube containing distilled water for sterilization in an autoclave at $121^{\circ} \mathrm{C}$ for 20 min.

The microbiological procedures and manipulation of the dentine blocks were performed within a laminar flow chamber (Telstar Technologies S.L./BV 100, Terrassa, Spain). A standard strain of E. faecalis (ATCC 29212) was used for biofilm formation. The microorganisms was reactivated in $4 \mathrm{~mL}$ of sterile Brain Heart Infusion broth (BHI, Difco Laboratories Inc., Detroit, MI, USA) and kept in an oven at $37^{\circ} \mathrm{C}$ for $12 \mathrm{~h}$. The inoculum was adjusted in spectrophotometer (Model 600 Plus, Femto, São Paulo, SP, Brazil) equivalent to $10^{8} \mathrm{CFU} \mathrm{mL}^{-1}$.

The bovine dentine blocks were placed in 24-well culture plates and each well received $200 \mu \mathrm{L}$ of the inoculum and $1.8 \mathrm{~mL}$ of BHI medium. The well plates and bovine dentine block were kept in an incubator (Model 0816M20, Quimis Aparelhos Científicos Ltda., Diadema, SP, Brazil) under constant agitation and microaerophilic environment at 37 ${ }^{\circ} \mathrm{C}$ for 14 days. The biofilm formed using this methodology was described by Guerreiro-Tanomaru et al. (20). The BHI medium of each well was completely changed every $48 \mathrm{~h}$, without adding new microorganisms.

After the post-manipulation period of 2 days, each sample was removed from the mold, sterilized by UV light and placed over a dentine block containing biofilm, which was previously washed in saline solution to remove the planktonic bacteria. The dentine block/cement samples were placed in a 48-well plate. For each sample, $20 \mu \mathrm{L}$ of sterile saline solution was added to prevent dehydration. The plates were kept at $37^{\circ} \mathrm{C}$ for the $5 \mathrm{~h}$ and $15 \mathrm{~h}$ of contact times. Six discs of each material were used for each period. In the control group, Teflon samples with the same size of the cement discs were used. After the contact time, the cement discs were removed and the dentine blocks with remaining biofilm were individually placed in test tubes with $1 \mathrm{~mL}$ of sterile saline solution and two glass pearls. The tubes were agitated in vortex (Model 0220; Quimis Aparelhos Científicos Ltda., Diadema, SP, Brazil) for 1 min 
to detach the remaining biofilm.

After this, decimal serial dilutions of $E$. faecalis were obtained. Three aliquots of $20 \mu \mathrm{L}$ of each dilution were inoculated in a Petri dish with Tryptic Soy agar medium (Difco Laboratories - Becton Dickinson and Company USA) and stored in a microaerophilic environment at 37 ${ }^{\circ} \mathrm{C}$ for $48 \mathrm{~h}$.

The readings for each plate resulted in a mean CFU $\mathrm{mL}^{-1}$ value. The number of CFU $\mathrm{mL}^{-1}$ was calculated for each material in each period. The data were submitted to base 10 logarithmic transform .

\section{Results}

\section{Physicochemical Properties}

The results are in Table 2. WMTA had the highest radiopacity, showing values statistically similar to $\mathrm{PC} /$ $\mathrm{ZrO}_{2}$ and WMTA/AgNPs, while the lowest radiopacity was observed for $\mathrm{PC} / \mathrm{ZrO}_{2} / \mathrm{AgNPs}$. The shortest observed setting times were for WMTA/AgNPs, which presented statistically difference from all other groups. The greatest observed setting times were for $\mathrm{PC} / \mathrm{ZrO}_{2} / \mathrm{AgNPs}$. Addition of AgNPs to $P C$ increased its compressive strength at $24 \mathrm{~h}$ and at 21 days after mixing, with statistically significant difference from the other groups. WMTA and WMTA/AgNPs were statistically similar in both periods. The WMTA/AgNPs group presented the highest $\mathrm{pH}$ at 2 and 7 days, showing statistically significant difference compared to the other groups. WMTA had the lowest $\mathrm{pH}$ in both periods. At 2 and 7 days, WMTA/AgNPs and $\mathrm{PC} / \mathrm{ZrO}_{2} / \mathrm{AgNPs}$ presented the lowest solubility and were statistically similar to each other. The greatest solubility was observed for WMTA and $\mathrm{PC} / \mathrm{ZrO}_{2}$.

\section{Antibacterial Activity}

In the direct contact test against planktonic cells using freshly mixed cement, the results showed that $\mathrm{PC} / \mathrm{ZrO}_{2}$ and $\mathrm{PC} / \mathrm{ZrO}_{2} / \mathrm{AgNPs}$ presented higher bacterial reduction $(p<0.05)$ in comparison with the other groups after $5 \mathrm{~h}$ contact. MTA/AgNPs presented a higher level of bacterial reduction than MTA, which was similar to control ( $p>0.05$ ). In the $15 \mathrm{~h}$ contact time, all the groups presented significant reduction in $E$. faecalis when compared with control (Table 3).

Table 4 shows the mean values of CFU $\mathrm{mL}^{-1}$ transformed into $\log _{10}$, after 5 and $15 \mathrm{~h}$ contact of the cements after post-manipulation periods of 2 days with the biofilm. MTA was similar to the control group in the $5 \mathrm{~h}$ contact. Reduction of microorganisms was observed for the other materials in comparison with the control $(p<0.05)$. After $15 \mathrm{~h}$ of contact with the biofilms, all the groups presented significant difference when compared with the control group, with a higher level of bacterial reduction for MTA/ AgNPs and $\mathrm{PC} / \mathrm{ZrO}_{2} / \mathrm{AgNPs}$. No material provided total elimination of the biofilm.

\section{Discussion}

The results of this study showed that all the cements presented radiopacity higher than $3 \mathrm{mmAl}$, as recommended by ISO 6876:2012 (14). One of the disadvantages of MTA is its long setting time, which may result in higher solubility (7). In the present study, WMTA/AgNPs had shorter setting time in comparison with the other groups, which may represent an advantage for this material. One possible explanation to this fact is the ability of silver nanoparticles (4-11 nm) to penetrate in the cement porosities, accelerating the

Table 2. Mean and standard deviation for the physicochemical and mechanical properties

\begin{tabular}{|c|c|c|c|c|c|}
\hline & & W MTA & $\mathrm{PC} / \mathrm{ZrO}_{2}$ & W MTA/AgNPs & $\mathrm{PC} / \mathrm{ZrO}_{2} / \mathrm{AgNPs}$ \\
\hline \multirow{2}{*}{ Setting times (min) } & Initial & $25.17 \pm 2.639^{b}$ & $43.17 \pm 2.401^{c}$ & $21.67 \pm 1.033^{\mathrm{a}}$ & $90.67 \pm 1.862^{\mathrm{d}}$ \\
\hline & Final & $171 \pm 1.789^{c}$ & $150.3 \pm 1.751^{\mathrm{b}}$ & $134.8 \pm 1.722^{\mathrm{a}}$ & $191.7 \pm 1.751^{\mathrm{d}}$ \\
\hline \multirow{2}{*}{ Compressive strength (MPa) } & $24 \mathrm{~h}$ & $17.13 \pm 3.123^{c}$ & $27.80 \pm 5.117^{b}$ & $15.29 \pm 2.611^{\mathrm{c}}$ & $34.84 \pm 5.460^{\mathrm{a}}$ \\
\hline & 21 days & $32.01 \pm 6.003^{\text {b.c }}$ & $23.18 \pm 2.289^{c}$ & $34.3 \pm 5.271^{\mathrm{b}}$ & $56.46 \pm 9.611^{\mathrm{a}}$ \\
\hline Radiopacity (mmAl) & 2 days & $4.841 \pm 0.2624^{\mathrm{a}}$ & $4.749 \pm 0.2814^{\mathrm{a}}$ & $4.464 \pm 0.3478$ ac & $4.195 \pm 0.3503^{b c}$ \\
\hline \multirow{4}{*}{$\mathrm{pH}$} & 2 days $5 h$ & $10.79 \pm 0.08790^{c}$ & $11.21 \pm 0.1329^{\mathrm{a}}$ & $11.15 \pm 0.06736^{\mathrm{a}}$ & $10.96 \pm 0.09994^{b}$ \\
\hline & 2 days $15 \mathrm{~h}$ & $10.99 \pm 0.07739^{c}$ & $11.31 \pm 0.08990^{\mathrm{b}}$ & $11.47 \pm 0.08042^{\mathrm{a}}$ & $11.27 \pm 0.1032^{\mathrm{b}}$ \\
\hline & 7 days $5 \mathrm{~h}$ & $10.83 \pm 0.1638^{b}$ & $10.59 \pm 0.1151^{\mathrm{c}}$ & $11.05 \pm 0.1886^{\mathrm{a}}$ & $10.73 \pm 0.2293^{c}$ \\
\hline & 7 days $15 \mathrm{~h}$ & $10.91 \pm 0.1641^{c}$ & $10.90 \pm 0.08923^{c}$ & $11.40 \pm 0.1454^{\mathrm{a}}$ & $11.13 \pm 0.1726^{b}$ \\
\hline \multirow[b]{2}{*}{ Solubility (\%) } & 2 days & $3.675 \pm 0.8546^{b}$ & $3.551 \pm 0.5959^{b}$ & $1.855 \pm 0.6308^{a}$ & $1.264 \pm 0.4090^{\mathrm{a}}$ \\
\hline & 7 days & $5.036 \pm 2.786^{b}$ & $5.692 \pm 2.786^{b}$ & $2.389 \pm 0.3914^{\mathrm{a}}$ & $1.531 \pm 0.6695^{a}$ \\
\hline
\end{tabular}

Different superscript letters in the same row indicate statistically significant difference $(\mathrm{p}<0.05)$. PC: Portland cement; $\mathrm{ZrO}_{2}$ : zirconium oxide; AgNPs: silver nanoparticles. 
hydration of silicates and reducing the setting time. The $\mathrm{PC} / \mathrm{ZrO}_{2}$ combined with AgNPs solution showed an increase in setting time. Addition of radiopacifier agents has been shown to increase the setting time of cements (21), possibly due to interference in the hydration mechanism of PC, delaying matrix formation.

Several factors may affect the mechanical properties of PC, like the powder/liquid ratio and the size and shape of the specimens. The powder/liquid ratio may affect the properties of PC. When MTA was manipulated with silver nanoparticles solution, the amount of liquid was increased to achieve a material with proper clinical consistency. Since the amount of radiopacifier is not the same for the materials, the ratio of water/cement is different. The water/cement ratio can affect the hydration and related properties, including antibacterial properties.

The increase in resistance over time indicates the material setting, enhancing its resistance and stability (1). In the present study, the compressive strength of MTA was lower than $\mathrm{CP} / \mathrm{ZrO}_{2}$ at $24 \mathrm{~h}$ and higher at 21 days, corroborating with Islam et al. (1). WMTA and WMTA/AgNPs presented similar compressive strength values. However, the resistance to compression was greater for $\mathrm{PC} / \mathrm{ZrO}_{2} / \mathrm{AgNPs}$. This may be due to the lower porosity of the material as result of the addition of AgNPs solution (22). Addition of nanoparticles promotes higher resistance to materials (23).

MTA and PC contain calcium oxide, which in contact with tissues or water turns into calcium hydroxide. All evaluated materials in this study showed alkaline $\mathrm{pH}$, according to Silva et al. (3), who evaluated the addition of $\mathrm{ZrO}_{2}$ (micro- and nanoparticles) to calcium silicatebased materials. Camilleri et al. (6) demonstrated that a prototype dental cement composed of PC and 30\% zirconium oxide as radiopacifier leached calcium ions and presented alkaline $\mathrm{pH}$.
MTA and $\mathrm{PC} / \mathrm{ZrO}_{2}$ had similar solubility, which is in accordance to Cutajar et al. (5). WMTA/AgNPs and PC/ $\mathrm{ZrO}_{2} / \mathrm{AgNPs}$ had lower solubility values in comparison with the other materials. This may be related to the lower porosity of the cement, due to the penetration of silver nanoparticles (22). The present study showed that the evaluated materials are in accordance with ISO 6876:2012 (14), which established solubility below $3 \%$.

Considering physicochemical and mechanical evaluation, the best results were presented by WMTA/NPsAg, which showed the highest $\mathrm{pH}$ values, less solubility, proper radiopacity and compressive strength, and lower setting time. $\mathrm{CP} / \mathrm{ZrO}_{2} / \mathrm{AgNPs}$ presented an alkaline $\mathrm{pH}$ ranging from 10.73 to 11.27 , proper radiopacity, low solubility and high compressive strength when compared to WMTA. The only disadvantage was the increase in setting time. Addition of accelerators may be suggested for improvement of this property.

Enterococcus faecalis is the prevalent bacterial species in cases of endodontic treatment failure (24). The failure of endodontic treatment is related to the persistence of microorganisms organized as microbial biofilm (17), and it is important to evaluate the materials' antimicrobial activity against this bacterial organization. Therefore, the methodology described by Faria-Junior et al. (17) allows materials to be evaluated in direct contact with $E$. faecalis strain organized in biofilms. One of the factors that affect the resistance of biofilm is related to its period of development (25). Biofilms incubated for short periods are not well structured and may not show resistance like a mature biofilm. The biofilm in the present study developed for 14 days and is considered mature, according to Guerreiro-Tanomaru et al. (20).

The antibacterial activity against $E$. faecalis was evaluated by direct contact test against planktonic cells and

Table 3. Mean values and standard deviation (SD) of turbidity of medium observed for each material

\begin{tabular}{|c|c|c|c|c|c|}
\hline Groups & WMTA & $\mathrm{PC} / \mathrm{ZrO}_{2}$ & WMTA/AgNPs & $\mathrm{PC} / \mathrm{ZrO}_{2} / \mathrm{AgNPs}$ & Control \\
\hline $5 \mathrm{~h}$ & 0.5933 bc $( \pm 0.153)$ & $0.1020^{a}( \pm 0.0432)$ & $0.4060^{\mathrm{b}}( \pm 0.312)$ & $0.1950^{\mathrm{a}}( \pm 0.136)$ & $0.7870^{c}( \pm 0.0884)$ \\
\hline $15 \mathrm{~h}$ & $0.06703^{\mathrm{a}}( \pm 0.00734)$ & $0.0726^{\mathrm{a}}( \pm 0.0528)$ & $0.06712^{\text {a }}( \pm 0.0697)$ & $0.07617^{\text {a }}( \pm 0.0830)$ & $0.3905^{b}( \pm 0.0486)$ \\
\hline
\end{tabular}

Same letters in the same row indicate statistically significant difference ( $>>0.05)$.

Table 4. Mean values (CFU mL $\mathrm{mL}^{-1} \log _{10}$ ) and standard deviation (SD) of the materials' antibiofilm activity 2 days after setting, considering 5 and $15 \mathrm{~h}$ of contact with biofilm

\begin{tabular}{lccccc}
\hline Time & WMTA & $\mathrm{CP} / \mathrm{ZrO}_{2}$ & WMTA/AgNPs & $\mathrm{CP} / \mathrm{ZrO}_{2} / \mathrm{AgNPs}$ & $\mathrm{Control}$ \\
\hline $5 \mathrm{~h}$ & $6.451^{\mathrm{ab}}( \pm 0.4573)$ & $6.391^{\mathrm{a}}( \pm 0.3679)$ & $5.921^{\mathrm{a}}( \pm 0.5776)$ & $5.777^{\mathrm{a}}( \pm 0.1859)$ & $7.110^{\mathrm{b}}( \pm 0.3594)$ \\
$15 \mathrm{~h}$ & $6.576^{\mathrm{b}}( \pm 0.5908)$ & $6.712^{\mathrm{b}}( \pm 0.2284)$ & $5.069^{\mathrm{a}}( \pm 0.3121)$ & $5.614^{\mathrm{a}}( \pm 0.3282)$ & $7.730{ }^{\mathrm{c}}( \pm .8958)$ \\
\hline
\end{tabular}

Same letters in the same row indicates statistically significant difference $(p>0.05)$. 
freshly mixed cement. Also an evaluation against biofilm and cement after 2 days setting was performed, using a methodology that investigates the materials in different periods after setting.

The direct contact test against planktonic cells demonstrated that $\mathrm{PC} / \mathrm{ZrO}_{2}$ and $\mathrm{PC} / \mathrm{ZrO}_{2} / \mathrm{AgNPs}$ presented a higher level of bacterial reduction after $5 \mathrm{~h}$, without statistical difference between them. Guerreiro-Tanomaru et al. (4) showed that the addition of $\mathrm{ZrO}_{2}$ does not interfere in the antibiofilm activity and provides radiopacity to PC, agreeing with the present study. There was no significant difference between experimental groups in the $15 \mathrm{~h}$ period. All groups showed reduction in E. faecalis compared with control group in the $15 \mathrm{~h}$ time interval.

After $5 \mathrm{~h}$ contact of 2-day setting materials and biofilm, all the cements except WMTA promoted a reduction in microorganisms. WMTA and control group were similar. WMTA/AgNPs and PC/ZrO2/AgNPs presented higher level of bacterial reduction after the $15 \mathrm{~h}$ period. No material provided total elimination of the biofilm.

The materials manipulated with the AgNPs solution provided a higher level of bacterial reduction of the E. faecalis biofilm. Similar results have been observed by Wu et al (24), who used a silver nanoparticle gel against $E$. faecalis biofilm for 7 days. They concluded that silver nanoparticles affected the structural integrity of the biofilm. Samiei et al. (13), demonstrated that the addition of $1 \%$ of silver nanoparticles to MTA improved its antibacterial property against $E$. faecalis, $C$. albicans and $P$. aeruginosa. Nanoparticles smaller than $10 \mathrm{~nm}$ were used and may interact directly with the bacteria $(11,13)$. Silver nanoparticles interact with the bacterial cell membrane and prevent DNA replication (12). After the adherence of nanoparticles to the bacterial membrane, possibly its permeability is affected, thereby facilitating a greater level of contact between the internal components of the bacteria with the ions released by MTA and PC.

Addition of silver nanoparticles to WMTA and $\mathrm{PC} / \mathrm{ZrO}_{2}$ favored the physicochemical and mechanical properties of the materials, and increased the effectiveness against both planktonic cells and E. faecalis biofilm. Additional studies on the biocompatibility and antimicrobial activity of these materials are required.

\section{Resumo}

Mineral trióxido agregado (MTA) e cimento Portland (CP) são cimentos à base de silicato de cálcio. Eles apresentam propriedades físico-químicas, mecânica e biológicas semelhantes. A adição de óxido de zircônio $\left(\mathrm{ZrO}_{2}\right)$ ao CP confere radiopacidade. Nanopartículas de prata (NPsAg) podem melhorar propriedades dos cimentos. 0 objetivo deste estudo foi avaliar o efeito da NPsAg nas propriedades físico-químicas, mecânicas e na atividade antibacteriana do MTA branco (WMTA) e CP associado ao $\mathrm{ZrO}_{2}$. Os seguintes materiais foram avaliados: WMTA; CP 70\% + $\mathrm{ZrO}_{2} 30 \%$; ; WMTA + NPsAg; $\mathrm{CP} 70 \%+\mathrm{ZrO}_{2} 30 \%+\mathrm{NPsAg}$. Foram avaliados a radiopacidade, tempo de presa, pH, resistência à compressão e solubilidade. Para análise da radiopacidade foram tiradas radiografias ao lado de uma escala de alumínio (Al). Para avaliar a atividade antibacteriana, foi realizado o teste de contato direto sobre células planctônicas e biofilme de Enterococcus faecalis formado em dentina radicular bovina durante 14 dias. 0 s periodos experimentais foram 5 e $15 \mathrm{~h}$. Os dados foram obtidos como UFC $\mathrm{mL}-1$ e submetidos aos testes de ANOVA e Tukey $(p<0,05)$. A adição de NPsAg ao WMTA elevou o $\mathrm{pH}$, diminuiu a solubilidade e os tempos de presa inicial e final. A adição de NPsAg ao $\mathrm{CP} / \mathrm{ZrO} 2$ manteve o $\mathrm{pH}$, diminuiu a solubilidade, aumentou o tempo de presa e a resistência à compressão. A radiopacidade de todos os materiais foi maior do que $4 \mathrm{mmAl}$. A adição de NPsAg promoveu um aumento da atividade antibacteriana dos cimentos à base de silicato de cálcio e favoreceu as propriedades físico-quimicas e mecânicas dos materiais.

\section{Acknowledgements}

To Adinael Trindade Junior (In memorian) for participating in all stages of this study. To the São Paulo State Research Support Foundation (FAPESP) for financial support (Grants 2012/11318-9 and 2012/13271-0).

\section{References}

1. Islam I, Chng HK, Yap AU. Comparison of the physical and mechanical properties of MTA and portland cement. J Endod 2006;32:193-197.

2. Camilleri J. Hydration mechanisms of mineral trioxide aggregate. Int Endod J 2007;40:462-470.

3. Silva GF, Bosso R, Ferino RV, Tanomaru-Filho M, Bernardi MI, GuerreiroTanomaru JM, et al.. Microparticulated and nanoparticulated zirconium oxide added to calcium silicate cement: Evaluation of physicochemical and biological properties. J Biomed Mater Res A 2014;102:4336-4345.

4. Guerreiro-Tanomaru JM, Trindade-Junior A, Costa BC, Silva GF, Drullis Cifali L, Basso Bernardi MI, et al.. Effect of zirconium oxide and zinc oxide nanoparticles on physicochemical properties and antibiofilm activity of a calcium silicate-based material. Scientific World Journal 2014 [Epub Ahead of Print. doi: 10.1155/2014/975213].

5. Cutajar A, Mallia B, Abela S, Camilleri J. Replacement of radiopacifier in mineral trioxide aggregate; characterization and determination of physical properties. Dent Mater 2011;27:879-891.

6. Camilleri J, Cutajar A, Mallia B. Hydration characteristics of zirconium oxide replaced Portland cement for use as a root-end filling material. Dent Mater 2011;27:845-854.

7. Leal F, De-Deus G, Brandao C, Luna A, Souza E, Fidel S. Similar sealability between bioceramic putty ready-to-use repair cement and white MTA. Braz Dent J 2013;24:362-366.

8. Camilleri J, Gandolfi MG. Evaluation of the radiopacity of calcium silicate cements containing different radiopacifiers. Int Endod J 2010;43:21-30

9. Jacquart $S$, Siadous $R$, Henocq-Pigasse $C$, Bareille $R$, Roques $C$, Rey $\mathrm{C}$, et al.. Composition and properties of silver-containing calcium carbonate-calcium phosphate bone cement. J Mater Sci Mater Med 2013;24:2665-2675.

10. Pissiotis E, Spangberg L. Reaction of bony tissue to implanted silver glass ionomer and a reinforced zinc oxide-eugenol cement. Oral Surg Oral Med Oral Pathol Oral Radiol Endod 2000;89:623-629.

11. Bahador A, Pourakbari B, Bolhari B, Hashemi FB. In vitro evaluation of the antimicrobial activity of nanosilver-mineral trioxide aggregate against frequent anaerobic oral pathogens by a membrane-enclosed immersion test. Biomed J 2015;38:77-83.

12. Neves PB, Agnelli JA, Kurachi C, de Souza CW. Addition of silver nanoparticles to composite resin: effect on physical and bactericidal properties in vitro. Braz Dent J 2014;25:141-145.

13. Samiei M, Aghazadeh M, Lotfi M, Shakoei S, Aghazadeh Z, Vahid Pakdel SM. Antimicrobial efficacy of mineral trioxide aggregate with and without silver nanoparticles. Iran Endod J 2013;8:166-170.

14. International Organization for Standardization. Dentistry - Root Canal Sealing Materials. ISO 6876. London, UK: British Standards Institution; 2012. 
15. International Standard Test Method for time of setting of hydraulic cement paste by Gillmore needles ASTM C266-07; 2007.

16. British Standard Institution. British Standard Specification for Dental Glass Ionomer Cement BS 6039: 1981. London, UK: British Standards Institution; 1981.

17. Faria-Junior NB, Tanomaru-Filho $\mathrm{M}$, Berbert $\mathrm{FL}$, Guerreiro-Tanomaru JM. Antibiofilm activity, $\mathrm{pH}$ and solubility of endodontic sealers. Int Endod J 2013;46:755-762.

18. Baer J, Maki JS. In vitro evaluation of the antimicrobial effect of three endodontic sealers mixed with amoxicillin. J Endod 2010;36:1170-1173.

19. Yalcin $M$, Arslan U, Dundar A. Evaluation of antibacterial effects of pulp capping agents with direct contact test method. Eur J Dent 2014;8:9599.

20. Guerreiro-Tanomaru JM, de Faria-Junior NB, Duarte MA, OrdinolaZapata R, Graeff MS, Tanomaru-Filho M. Comparative analysis of Enterococcus faecalis biofilm formation on different substrates. J Endod 2013;39:346-350.

21. Camilleri J. Evaluation of the physical properties of an endodontic Portland cement incorporating alternative radiopacifiers used as rootend filling material. Int Endod J 2010;43:231-240.
22. de Moura MR, Aouada FA, Mattoso LH, Zucolotto V. Hybrid nanocomposites containing carboxymethylcellulose and silver nanoparticles. J Nanosci Nanotechnol 2013;13:1946-1950.

23. Akbari M, Zebarjad SM, Nategh B, Rouhani A. Effect of nano silica on setting time and physical properties of mineral trioxide aggregate. J Endod 2013;39:1448-1451.

24. Wu D, Fan W, Kishen A, Gutmann JL, Fan B. Evaluation of the antibacterial efficacy of silver nanoparticles against Enterococcus faecalis biofilm. J Endod 2014;40:285-290.

25. Norrington DW, Ruby J, Beck P, Eleazer PD. Observations of biofilm growth on human dentin and potential destruction after exposure to antibiotics. Oral Surg Oral Med Oral Pathol Oral Radiol Endod 2008;105:526-529. 